https://ejournal.iai-tribakti.ac.id/index.php/psikologi

https://doi.org/10.33367/psi.v6i2.2032

\title{
Kekuatan Karakter Mahasiswa di Tengah Pandemi Covid-19
}

\author{
Hetti Sari Ramadhani ${ }^{1}$, Jatie K. Pudjibudojo ${ }^{2}$, Lena Panjaitan ${ }^{3 *}$ \\ Universitas 17 Agustus 1945 Surabaya, Universitas Surabaya \\ ${ }^{1}$ hetti_sari@untag-sby.ac.id, ${ }^{2}$ jatiekpudjibudojo@yahoo.co.id, ${ }^{3}$ lenapanjaitan66@gmail.com \\ *Correspondence
}

\section{Article Information:}

Received 14 November 2021

Revised 23 November 2021

Accepted 25 November 2021

\section{Keywords:}

character strengths; students; covid-19 pandemic
Kata Kunci:

kekuatan karakter; mahasiswa; pandemic covid19

\section{Abstract}

The main challenge for educational institutions in the middle of the pandemic is fostering students to maintain character strengths in poor conditions. Various difficulties come quickly, such as changes in the online learning system, strict health protocols that apply to the threat of viruses that are scary all the time. Character strengths have a broad impact on life satisfaction, subjective well-being, friendly relationships, and academic success. This study aims to determine the condition of initial student character strengths, especially those who have just entered college, as positive traits used in dealing with changes during the COVID19 pandemic and contribute to the development of character strengths theory. Peterson-Seligman. The research subjects were 145 students who filled out the 72-item VIA-IS scale online and analyzed using descriptive analysis. The results showed that most early students had high character strengths (68.3\%) and responded to change by highlighting their signature strengths of kindness, humor, love, honesty, and gratitude. This research is expected to describe the strength of character as an effort to adapt to change in the middle of the covid-19 pandemic.

\section{Abstrak}

Tantangan utama bagi institusi pendidikan di tengah pandemi adalah membina peserta didik untuk tetap memiliki kekuatan karakter di tengah kondisi yang tidak menguntungkan. Berbagai kesulitan datang secara cepat seperti perubahan sistem pembelajaran daring, protokol kesehatan ketat yang berlaku hingga ancaman virus yang menakutkan sepanjang waktu. Kekuatan karakter berdampak luas pada kepuasan hidup, subjective well being, hubungan persahabatan dan keberhasilan akademik Penelitian ini bertujuan untuk mengetahui kondisi kekuatan karakter mahasiswa terutama yang baru memasuki perguruan tinggi, sebagai sifat positif yang digunakan dalam menghadapi perubahan yang terjadi di tengah pandemi covid-19 serta berkontribusi pada pengembangan teori character strengths Peterson-Seligman. Subjek penelitian adalah 145 mahasiswa yang mengisi skala VIA-IS 72 aitem secara online dan dianalis menggunakan analisa deskriptif. Hasil penelitian menunjukkan bahwa mahasiswa awal mayoritas memiliki kekuatan karakter yang tinggi $(68,3 \%)$ serta menyikapi perubahan dengan menonjolkan karakter inti (signature strengths) kebaikan, humor, cinta, jujur, dan bersyukur. Penelitian ini diharapkan memberi 
kontribusi dalam menggambarkan kekuatan karakter sebagai upaya adaptasi perubahan di tengah pandemi covid-19.

\section{PENDAHULUAN}

Pandemi COVID-19 telah menyebabkan darurat kesehatan masyarakat Internasional dengan berbagai konsekuensi pada aspek politik, ekonomi, sosial dan budaya. Penyakit ini dinyatakan sebagai pandemi oleh Organisasi Kesehatan Dunia (WHO) sejak tanggal 11 Maret 2020, dengan jumlah 252.826.597 kasus dikonfirmasi di seluruh dunia dan jumlah kematian 5.092 .761 per tanggal 16 November 2021. Kasus terbanyak di kawasan Asia Tenggara ditemukan di India dengan peningkatan kasus dan peningkatan kematian tertinggi dan Indonesia menjadi peringkat kedua setelah India. WHO mendesak Kawasan Asia Tenggara untuk memperkuat layanan Kesehatan mental dalam memenuhi kebutuhan dan mengisi kesenjangan yang buruk selama pandemi (WHO, 2021).

Penelitian Martínez-Martí dkk (2020) menunjukkan pentingnya kekuatan karakter dalam meningkatkan kesehatan mental dan subjective well being selama masa lockdown akibat pandemi covid-19. Informasi yang salah kerap menjadi kepanikan yang berujung stress selama masa isolasi dan (Umucu dkk., 2021) juga membuktikan peran kekuatan karakter sebagai proteksi kondisi stress pada diri seseorang. Dampak besar lainnya dari kekuatan karakter adalah peningkatan dalam kepuasan hidup, subjective well being, keberhasilan akademik, penerimaan teman sebaya, dan kualitas persahabatan (Proctor dkk., 2011; Wagner, 2019; Wagner \& Ruch, 2015). Penelitian Subhashini (2020) memperkuat fungsi kekuatan karakter sebagai modal pemulihan dunia dalam menghadapi covid-19.

Banyak penelitian pada beberapa dekade terakhir yang memfokuskan pada pentingnya karakter pada diri remaja (Ferragut dkk., 2014; Ngai, 2015; Raimundi dkk., 2019; Ros-Morente dkk., 2017; Ruch dkk., 2014; Weber dkk., 2016) bahkan riset oleh Lavy (2020) menggambarkan pentingnya character strengths pada setiap institusi pendidikan di abad 21. Kekuatan karakter remaja menjadi garda terdepan bagi generasi penerus bangsa untuk menghadapi setiap tantangan termasuk saat terjadi perubahan proses belajar selama pandemi covid-19. Keseriusan dalam menangani karakter remaja di Indonesia juga diperkuat pada PERPRES No 87 tahun 2017 tentang penguatan pendidikan karakter dalam lingkup pendidikan formal, non formal maupun informal (Perpres, 2017).

Lebih dari satu tahun pandemi covid-19 di Indonesia menimbulkan perilaku baru dalam diri remaja termasuk mahasiswa di perguruan tinggi. Mahasiswa sebagai generasi penerus bangsa yang sedang menyelesaikan tugas perkembangan, harus melakukan adaptasi yang baik dalam proses belajar, bersosialisasi maupun dalam pengembangan diri dan karir. Keterbatasan selama pandemi mendorong kekuatan karakter untuk tampil dalam kondisi yang survive di tengah ketidakpastian. Mahasiswa dituntut mampu menyesuaikan perubahan yang cepat dengan segala kebijakan yang berlaku selama 
pandemi covid-19 mulai pembatasan sosial berskala besar, aturan belajar dan kuliah daring.

Pemberlakuan Pembatasan Kegiatan Masyarakat (PPKM) membuat mahasiswa lebih banyak menghabiskan waktu di rumah dengan belajar daring, bahkan ada yang tidak bisa melanjutkan studi akibat pemutusan hubungan kerja pada orang tua sebagai sumber penghasilan keluarga. Belajar dari rumah tidak mudah karena membutuhkan usaha yang lebih besar untuk selalu fokus dalam lingkungan belajar yang terkadang tidak kondusif. Kesulitan belajar dari rumah secara daring diantaranya komunikasi terbatas secara virtual dengan guru atau dosen melalui wa, email, zoom meeting, google meet, aplikasi lainnya, kesulitan signal dan kesulitan konsentrasi akibat suasana rumah yang belum tentu kondusif dalam proses belajar.

Mahasiswa awal yang baru memasuki perguruan tinggi harus mengikuti kebijakan perkuliahan daring sehingga belum bisa banyak mengeksplorasi hal-hal baru seperti mengenal teman kelas, bertemu dosen, diskusi akademik dan berpartisipasi dalam pertemuan ilmiah serta atmosfir akademik lainnya di perguruan tinggi. Satu tahun pembelajaran daring melewatkan banyak kesempatan yang sebenarnya bisa dilakukan oleh mahasiswa di perguruan tinggi. Pembelajaran daring di rumah juga tidak mudah dilakukan karena lingkungan belajar yang tidak kondusif dan melelahkan.

Kekuatan karakter mahasiswa di tengah pandemi covid-19 dapat dikatakan sebagai penolong sehingga perlu dikenalkan dan ditumbuhkan dalam menjalani rutinitas. Kekuatan karakter (character strengths) merupakan sifat positif yang tercermin pada level kognitif, emosional, dan perilaku (Park, \& Peterson, 2009). Karakter ini disusun dari enam kelompok kekuatan manusia yaitu Kebijaksanaan dan Pengetahuan, Keberanian, Kemanusiaan, Keadilan, Pengendalian diri, dan Transendensi. Enam kebajikan diturunkan menjadi 24 nilai yaitu kreatif, keingintahuan, cinta belajar, keterbukaan pikiran dan perspektif, keberanian, ketekunan, integritas, vitalitas, kebaikan, cinta, kecerdasan social kerjasama, kejujuran, kepemimpinan, regulasi diri, kehati-hatian, kerendahan hati, memaafkan, apresiasi terhadap keindahan dan kebaikan, harapan, bersyukur, humor dan spiritualitas (Seligman \& Peterson, 2004).

Penelitian ini bertujuan untuk melihat gambaran kekuatan karakter mahasiswa sebagai sifat positif yang digunakan dalam menghadapi perubahan yang terjadi di tengah pandemi covid-19 serta berkontribusi pada pengembangan teori character strengths Peterson -Seligman.

\section{METODE}

Penelitian ini menggunakan desain penelitian kuantitatif deskriptif. Penelitian ini menggambarkan kekuatan karakter mahasiswa selama menjalani pembelajaran daring dan menjadi studi pendahuluan untuk mengidentifikasi potensi perkembangan kekuatan karakter yang dimiliki mahasiswa.

Partisipan dalam penelitian ini adalah mahasiswa awal di Perguruan Tinggi swasta 
yang memiliki rentang usia 19-20 tahun dan dapat dikatakan berada pada tahapan remaja akhir. Seluruh subjek menjalani proses belajar secara daring baik melalui zoom meeting, google meet, google classroom, skype dan subjek memiliki akses media teknologi informasi yang baik selama mengikuti sistem daring.

Pengambilan data dilakukan pada 145 mahasiswa awal yang sedang menjalani perubahan pembelajaran dari offline di sekolah menjadi online dari rumah sejak adanya pandemi covid-19. Kekuatan karakter mahasiswa dikumpulkan secara daring melalui website www.viacharacter.org.

Instrument yang digunakan adalah Values in Action Assesment dari teori Seligman dan Peterson dengan pembagian usia yaitu alat ukur Values in Action-IS (VIA-IS) untuk usia 18 tahun keatas yang digunakan untuk mahasiswa. Skala ini terdiri dari 72 pertanyaan. Psikometri alat ukur diperoleh nilai internal reliabilitas sebesar 0,75 sedangkan validitas dari alat ukur VIA-IS berkisar antara 0,36 - 0,48. Karakter mahasiswa diukur dengan pertanyaan dengan contoh sebagai berikut "apapun situasinya, saya bisa menyesuaikan diri" dan "salah satu kekuatan saya adalah membantu sekelompok orang untuk bekerjasama dengan baik saat mereka memiliki banyak perbedaan".

Analisis data yang digunakan adalah analisis dekriptif. Analisis deskriptif yang dilakukan adalah dari nilai minimal, nilai maksimal, rata-rata, standar deviasi serta frekuensi

\section{PAPARAN HASIL}

Hasil penghitungan pada 145 mahasiswa, diperoleh gambaran sebagai berikut :

Tabel 1. Statistik Deskriptif

\begin{tabular}{ccccccccccc}
\hline & Hipotetik & \multicolumn{1}{c}{ Empirik } \\
\hline & $\mathrm{N}$ & Min & Max & Mean & SD & N & Min & Max & Mean & SD \\
Total & 145 & 72 & 360 & 216 & 48 & 145 & 204 & 360 & 276,47 & 28,33 \\
\hline
\end{tabular}

Berdasarkan tabel 1 menunjukkan mean hipotetik lebih rendah dari mean empirik yang artinya kekuatan karakter dari mahasiswa sebagai subyek penelitian cenderung tinggi. Pada skor SD hipotetik menunjukkan skor lebih besar dibandingkan skor SD empirik sehingga dapat disimpulkan bahwa skor yang diperoleh masing-masing subyek terlihat jauh berbeda. Jika diuraikan dapat dilihat sebarannya dari tabel berikut ini:

Tabel 2. Kategori Data

\begin{tabular}{cccc}
\hline Kategori & Jumlah & Prosentase & Norma \\
\hline Rendah & 0 & 0 & $\mathrm{X}<168$ \\
Sedang & 46 & 31,7 & $168 \leq \mathrm{X}<264$ \\
Tinggi & 99 & 68,3 & $264 \leq \mathrm{X}$ \\
\hline
\end{tabular}

Berdasarkan tabel 2 menunjukkan mahasiswa tergolong memiliki kekuatan karakter tinggi sebanyak 99 orang, yang memiliki kekuatan karakter rendah sebanyak 46 orang dan yang memiliki kekuatan karakter rendah tidak ada. Kekuatan karakter inti 
diambil dari karakter tertinggi dan yang lebih dominan muncul pada mahasiswa. Berikut gambaran kekuatan karakter tertinggi dapat dilihat dalam tabel berikut ini :

Tabel 3. Gambaran Kekuatan Karakter

\begin{tabular}{|c|c|}
\hline Karakter & Prosentase \\
\hline Kindness (baik hati) & $41,6 \%$ \\
\hline Humor (humor) & $29,1 \%$ \\
\hline Love (cinta) & $16,6 \%$ \\
\hline Gratitude (bersyukur) & $12,5 \%$ \\
\hline Honesty (jujur) & $12,5 \%$ \\
\hline Perseverance (tekun) & $8,3 \%$ \\
\hline Creativity (kreatifitas) & $8,3 \%$ \\
\hline Prudence (hati-hati) & $8,3 \%$ \\
\hline Fairness (adil) & $8,3 \%$ \\
\hline Forgiveness (memaafkan) & $8,3 \%$ \\
\hline Judgment (menilai) & $8,3 \%$ \\
\hline Curiosity (ingin tau) & $4,16 \%$ \\
\hline Hope (harapan) & $4,16 \%$ \\
\hline Appreciation of Beauty \& Excellence (menyukai keindahan) & $4,16 \%$ \\
\hline Teamwork (kerjasama) & $4,16 \%$ \\
\hline Bravery (keberanian) & $4,16 \%$ \\
\hline Leadership (kepemimpinan) & $4,16 \%$ \\
\hline Love of learning (cinta belajar) & $4,16 \%$ \\
\hline Humility (rendah hati) & $4,16 \%$ \\
\hline Perspective (perspektif) & $4,16 \%$ \\
\hline Self-Regulation (regulasi diri) & $4,16 \%$ \\
\hline Social Intelligence (kecerdasan sosial) & $4,16 \%$ \\
\hline Spirituality (spiritual) & $4,16 \%$ \\
\hline
\end{tabular}

Hasil penghitungan pada tabel 3 menunjukkan mahasiswa secara memiliki kekuatan karakter tertinggi yaitu karakter baik hati, humor, cinta, jujur, dan bersyukur. Berikut data ringkasan prosentase tertinggi kekuatan karakter mahasiswa :

Table 4. Prosentase Tertinggi Karakter Mahasiswa

\begin{tabular}{cccccc}
\hline & Baik Hati & Humor & Cinta & Jujur & Bersyukur \\
\hline Prosentase & $41,6 \%$ & $29,1 \%$ & $16,6 \%$ & $12,5 \%$ & $12,5 \%$ \\
\hline
\end{tabular}

\section{Kekuatan Karakter Baik Hati}

Hasil penghitungan dari 145 mahasiswa menunjukkan mayoritas mahasiswa memiliki kekuatan karakter baik hati yang tinggi, kemudian diikuti mahasiswa dengan kekuatan karakter baik hati sedang dan tidak ada mahasiswa yang memiliki kekuatan karakter baik hati rendah. Penggolongan kekuatan karakter baik hati sebagai berikut :

Tabel 5. Kategori kekuatan karakter baik hati

\begin{tabular}{ccc}
\hline Kategori & Jumlah & Prosentase \\
\hline Rendah & 0 & 0 \\
Sedang & 5 & 3 \\
Tinggi & 140 & 97 \\
\hline
\end{tabular}




\section{Kekuatan Karakter Humor}

Hasil penghitungan dari 145 mahasiswa menunjukkan mayoritas mahasiswa memiliki kekuatan karakter humor yang tinggi, kemudian diikuti mahasiswa dengan kekuatan karakter humor sedang dan hanya satu mahasiswa yang memiliki kekuatan karakter humor rendah. Penggolongan kekuatan karakter humor sebagai berikut :

Tabel 6. Kategori kekuatan karakter humor

\begin{tabular}{ccc}
\hline Kategori & Jumlah & Prosentase \\
\hline Rendah & 1 & 1 \\
Sedang & 17 & 12 \\
Tinggi & 127 & 87 \\
\hline
\end{tabular}

\section{Kekuatan Karakter Cinta}

Hasil penghitungan dari 145 mahasiswa menunjukkan mayoritas mahasiswa memiliki kekuatan karakter cinta yang tinggi, kemudian diikuti mahasiswa dengan kekuatan karakter cinta sedang dan hanya dua mahasiswa yang memiliki kekuatan karakter cinta rendah. Penggolongan kekuatan karakter cinta sebagai berikut :

Tabel 7. Kategori kekuatan karakter cinta

\begin{tabular}{ccc}
\hline Kategori & Jumlah & Prosentase \\
\hline Rendah & 2 & 1 \\
Sedang & 55 & 38 \\
Tinggi & 88 & 61 \\
\hline
\end{tabular}

\section{Kekuatan Karakter Jujur}

Hasil penghitungan dari 145 mahasiswa menunjukkan mayoritas mahasiswa memiliki kekuatan karakter jujur yang tinggi, kemudian diikuti mahasiswa dengan kekuatan karakter jujur sedang dan hanya satu mahasiswa yang memiliki kekuatan karakter jujur rendah. Penggolongan kekuatan karakter jujur sebagai berikut :

Tabel 8. Kategori kekuatan karakter jujur

\begin{tabular}{ccc}
\hline Kategori & Jumlah & Prosentase \\
\hline Rendah & 1 & 1 \\
Sedang & 21 & 14 \\
Tinggi & 123 & 85 \\
\hline
\end{tabular}

\section{Kekuatan Karakter Bersyukur}

Hasil penghitungan dari 145 mahasiswa menunjukkan mayoritas mahasiswa memiliki kekuatan karakter bersyukur yang tinggi, kemudian diikuti mahasiswa dengan kekuatan karakter bersyukur sedang dan tidak ada mahasiswa yang memiliki kekuatan karakter bersyukur rendah. Penggolongan kekuatan karakter bersyukur sebagai berikut : 
Hetti Sari Ramadhani, dkk | Kekuatan Karakter Mahasiswa

Tabel 9. Kategori kekuatan karakter bersyukur

\begin{tabular}{ccc}
\hline Kategori & Jumlah & Prosentase \\
\hline Rendah & 0 & 0 \\
Sedang & 9 & 6 \\
Tinggi & 136 & 94 \\
\hline
\end{tabular}

\section{PEMBAHASAN}

Kekuatan karakter mahasiswa menjadi tameng dalam menghadapi kesulitan baik yang muncul dari dalam diri maupun yang dari luar. Subyek dalam penelitian mayoritas memiliki kekuatan karakter yang tinggi artinya mahasiswa dengan kekuatan karakter yang tinggi mampu menunjukkan sikap kreatif dengan menciptakan hal yang beguna dan memikirkan penyelesaian masalah secara produktif, memiliki rasa ingin tahu akan hal baru, berpikir kritis sebelum bertindak, senang belajar, memiliki sudut pandang yang luas dalam memahami situasi, berani menghadapi kesulitan, tekun mencapai tujuan, bersikap jujur, enerjik, menunjukkan cinta pada orang lain, melakukan hal baik untuk orang lain, memahami emosi orang lain, mampu berpartisipasi dalam kelompok, memperlakukan orang lain secara adil, memiliki kemampuan dalam memimpin, mampu memaafkan orang lain, tidak merasa lebih istimewa dibanding orang lain, berhati hati, mampu mengelola emosi diri, menyukai keindahan dan kebaikan, memiliki rasa syukur, memiliki harapan baik di masa depan, memiliki selera humor, dan memiliki keyakinan atas kekuatan yang lebih besar dari pencipta (Seligman \& Peterson, 2004).

Kekuatan karakter pada mahasiswa mengarahkan pada perilaku positif walaupun di tengah berbagai keterbatasan. Penelitian (Chalimah; Sa'adah, 2015) menjelaskan dampak adanya kekuatan karakter dengan peningkatan prestasi social akademik. Penelitian longitudinal (Kor dkk., 2019) juga menunjukkan dampak kekuatan karakter pada emosi positif, kepuasaan hidup dan sikap prososial. Mahasiswa yang memiliki kekuatan karakter lebih terhindar dari perilaku merusak seperti kekerasan, minum alcohol, mencuri dan menyakiti orang lain maupun diri sendiri. Hal ini sejalan dengan penelitian lain (Novita dkk., 2014) yang menemukan hubungan negatif antara kekuatan karakter remaja dengan perilaku bullying.

Mahasiswa dalam menyikapi keterbatasan dan kesulitan selama pandemi lebih berfokus pada kebajikan interpersonal seperti kebaikan hati, humor, cinta, jujur dan bersyukur. Kebajikan kemanusiaan menjadi kekhasan dari masyarakat Indonesia yang suka bergotong royong dan ramah. Masa Pandemi covid-19 membuat perubahan yang sangat besar dalam proses belajar. Belajar dari rumah dengan sistem daring seringkali menjadikan mahasiswa mengalami banyak kesulitan dalam belajar.

Mahasiswa mayoritas memiliki kekuatan karakter yang tinggi pada kebaikan hati, humor, cinta, jujur serta bersyukur. Mahasiswa sangat sedikit sekali yang memiliki kekuatan karakter rendah pada humor, cinta dan jujur. Tidak ada mahasiswa yang memiliki kekuatan rendah pada kebaikan hati dan kebersyukuran dalam menjalani harihari di tengah pandemi. Mahasiswa yang memiliki kekuatan karakter justru menunjukkan perilaku suka untuk melakukan hal baik pada orang lain sekecil apapun di rumah seperti 
menolong pekerjaan rumah, membantu pekerjaan saudara, membantu ayah dan ibu. Perilaku lain adalah cinta dan menyayangi pada orang lain termasuk pada keluarga, saudara dan tetangga. Mampu mengatakan apa yang benar pada orang lain, memiliki humor dengan menyikapi secara positif dan berusaha membangkitkan keceriaan di tengah permasalahan karena pandemi serta memiliki rasa syukur atas anugrah yang diberikan Tuhan di tengah pandemi covid-19 seperti kesehatan dan keselamatan.

Penelitian (Martínez-Martí dkk., 2020) menyebutkan dalam hasil penelitian bahwa kekuatan karakter baik hati, cinta, syukur, jujur dan humor merupakan kekuatan interpersonal. Karakter ini termasuk dalam kebajikan kemanusiaan yang meningkatkan kesehatan mental dan kepuasan hidup. Banyak dari kekuatan karakter ini secara langsung terkait dengan keadaan emosi positif (misalnya cinta, syukur) dan semuanya memfasilitasi hubungan yang positif walaupuan di tengah keterbatasan selama pandemi covid-19.

Mahasiswa yang mengoptimalkan kekuatan karakter inti atau tertinggi yang dimiliki akan semakin baik dalam pengembangan diri. Hal ini sesuai dengan Penelitian lain (Schutte \& Malouff, 2019) menunjukkan karakter inti memiliki bukti empiris untuk meningkatkan kesejahteraan dan pengembangan diri dibandingkan intervensi karakter lainnya. Karakter inti diambil dari lima atau enam kekuatan tertinggi dari 24 kekuatan karakter teori (Seligman \& Peterson, 2004).

Kekuatan karakter seorang mahasiswa menjadi bagian penting untuk mulai disadari terlebih disaat pandemi. Penelitian Subhashini (2020) menunjukkan kekuatan karakter sebagai modal pemulihan dari situasi pandemi yang tidak pasti. Penelitian lainnya Jeynes (2019) juga menunjukkan pendidikan karakter akan memberikan dampak yang jauh lebih besar dengan bukti yang lebih terlihat pada usia remaja dibandingkan pada saat usia anak. Hal ini juga sejalan dengan penelitian longitudinal (Ferragut dkk., 2014) yang menemukan bahwa karakter relatif stabil pada usia remaja. Penelitian terdahulu menunjukkan dampak yang besar dari kekuatan karakter pada kepuasan hidup, subjective well being, keberhasilan akademik, penerimaan teman sebaya, dan kualitas persahabatan (Proctor dkk., 2011; Wagner, 2019; Wagner \& Ruch, 2015).

\section{SIMPULAN}

Kesimpulan penelitian telah menunjukkan gambaran kekuatan karakter mahasiswa awal sebagai sifat positif yang digunakan dalam menghadapi perubahan yang terjadi di tengah pandemi covid-19. Mahasiswa memiliki kekuatan karakter yang tinggi sebagai tameng dalam menjalani aktifitas belajar yang tidak mudah di masa pandemi. Kekuatan karakter inti atau yang tertinggi pada diri mahasiswa menjadi perhatian untuk optimalisasi pengembangan diri. Mahasiswa dengan kekuatan karakter baik hati, humor, jujur, cinta dan bersyukur lebih menekankan pada karakter interpersonal yang mengarah pada kebajikan kemanusiaan. Mahasiswa dengan kekuatan karaker baik hati, humor, jujur, cinta dan bersyukur akan lebih berfokus pada kekuatan karakter interpersonal dalam 
menyikapi kesulitan-kesulitan di masa pandemi. Penelitian lain (Steen dkk., 2003) juga menguatkan bahwa kekuatan karakter yang terus dikembangkan oleh remaja tentu akan membantu tercapainya peningkatan hidup yang lebih baik dan sangat membantu untuk kehidupan di masa mendatang.

Penelitian Ramadhani (2020) menjelaskan bahwa di tingkat perguruan tinggi, kekuatan karakter mahasiswa semakin meningkat dari pendidikan menengah sebelumnya sehinggan penelitian ini diharapkan untuk membantu mengenali kekuatan karakter pada mahasiswa terutama yang baru memasuki perguruan tinggi dan memberikan edukasi tentang pentingnya peran kekuatan karakter untuk menghadapi situasi tidak nyaman di masa pandemi covid-19. Penelitian selanjutnya diharapkan lebih menjelaskan faktor determinan internal maupun eksternal yang menjadi pembentuk kekuatan karakter mahasiswa.

\section{UCAPAN TERIMA KASIH}

Penelitian ini merupakan penelitian mandiri sebagai studi pendahuluan dari penelitian disertasi. Ucapan terimakasih kepada tim penulis yaitu promotor Prof. Dr. Jatie K. Pudjibudojo, SU, Psikologi dan co-promotor Dr. Lena N. Pandjaitan, M.Pd., Psikolog yang mendukung penelitian serta kepada para mahasiswa Fakultas Psikologi Universitas 17 Agustus 1945 Surabaya selaku responden dalam penelitian ini.

\section{DAFTAR PUSTAKA}

Ferragut, M., Blanca, M. J., \& Ortiz-Tallo, M. (2014). Psychological virtues during adolescence: A longitudinal study of gender differences. Dalam European Journal of Developmental Psychology (Vol. 11, Nomor 5, hlm. 521-531). Taylor \& Francis. https://doi.org/10.1080/17405629.2013.876403

Jeynes, W. H. (2019). A Meta-Analysis on the Relationship Between Character Education and Student Achievement and Behavioral Outcomes. Education and Urban Society, 51(1), 33-71. https://doi.org/10.1177/0013124517747681

Kor, A., Pirutinsky, S., Mikulincer, M., Shoshani, A., \& Miller, L. (2019). A longitudinal study of spirituality, character strengths, subjective well-being, and prosociality in middle school adolescents. Frontiers in Psychology, 10(FEB). https://doi.org/10.3389/fpsyg.2019.00377

Lavy, S. (2020). A Review of Character Strengths Interventions in Twenty-First-Century Schools: Their Importance and How they can be Fostered. Applied Research in Quality of Life, 15(2), 573-596. https://doi.org/10.1007/s11482-018-9700-6

Martínez-Martí, M. L., Theirs, C. I., Pascual, D., \& Corradi, G. (2020). Character Strengths Predict an Increase in Mental Health and Subjective Well-Being Over a One-Month Period During the COVID-19 Pandemic Lockdown. Frontiers in Psychology, 11(October), 1-14. https://doi.org/10.3389/fpsyg.2020.584567 
Ngai, S. S. Y. (2015). Parental bonding and character strengths among Chinese adolescents in Hong Kong. International Journal of Adolescence and Youth, 20(3), 317-333. https://doi.org/10.1080/02673843.2015.1007879

Novita, L., Hastuti, D., \& Herawati, T. (2014). The influence of family atmosphere and parents' role-models on the characters of rural juveniles. Jurnal pendidikan karakter, 5(2), 184-194.

Perpres. (2017). Perpres no. 87 Tahun 2017. 6 September 2017.

Proctor, C., Tsukayama, E., Wood, A. M., Maltby, J., Eades, J. F., \& Linley, P. A. (2011). Strengths gym: The impact of a character strengths-based intervention on the life satisfaction and well-being of adolescents. Journal of Positive Psychology, 6(5), 377-388. https://doi.org/10.1080/17439760.2011.594079

Raimundi, M. J., Molina, M. F., Schmidt, V., \& Hernández-Mendo, A. (2019). Family functioning profiles and character strengths in young elite athletes from Argentina. International Journal of Sport and Exercise Psychology, 17(1), 32-51. https://doi.org/10.1080/1612197X.2016.1189949

Ramadhani, H.S., Pudjibudojo, J., Panjaitan, L. (2021). Character Strengths of Student and College Student Undergoing Learning Activities During the Covid-19 Pandemic. Proceedings of the International Conference on Psychological Studies (ICPSYCHE 2020). Atlantis Press SARL, Advances in Social Science, Education and Humanities Research, volume 530

Ros-Morente, A., Alsinet Mora, C., Torrelles Nadal, C., Blasco Belled, A., \& Jordana Berenguer, N. (2017). An examination of the relationship between emotional intelligence, positive affect and character strengths and virtues. Anales de Psicología, 34(1), 63. https://doi.org/10.6018/analesps.34.1.262891

Ruch, W., Platt, T., \& Hofmann, J. (2014). The character strengths of class clowns. Frontiers in Psychology, 5(SEP), 1-12. https://doi.org/10.3389/fpsyg.2014.01075

Schutte, N. S., \& Malouff, J. M. (2019). The Impact of Signature Character Strengths Interventions: A Meta-analysis. Journal of Happiness Studies, 20(4), 1179-1196. https://doi.org/10.1007/s10902-018-9990-2

Seligman, \& Peterson. (2004). Character Strenghts and Virtues.

Steen, T. A., Kachorek, L. V., \& Peterson, C. (2003). Character Strengths among Youth. Journal of Youth and Adolescence, 32(1), 5-16. https://doi.org/10.1023/A:1021024205483

Subhashini, P. (2020). Character Strengths for Post Covid-19 Growth. Journal of Community Guidance \& Research () Journal of Community Guidance \& Research Journal of Community Guidance \& Research, 37(1), 3-18.

Umucu, E., Tansey, T. N., Brooks, J., \& Lee, B. (2021). The Protective Role of Character Strengths in COVID-19 Stress and Well-Being in Individuals With Chronic 
Conditions and Disabilities: An Exploratory Study. Rehabilitation Counseling Bulletin, 64(2), 67-74. https://doi.org/10.1177/0034355220967093

Wagner, L. (2019). Good Character Is What We Look for in a Friend: Character Strengths Are Positively Related to Peer Acceptance and Friendship Quality in Early Adolescents. Journal of Early Adolescence, 39(6), 864-903. https://doi.org/10.1177/0272431618791286

Wagner, L., \& Ruch, W. (2015). Good character at school: Positive classroom behavior mediates the link between character strengths and school achievement. Frontiers in Psychology, 6(MAY), 1-13. https://doi.org/10.3389/fpsyg.2015.00610

Weber, M., Wagner, L., \& Ruch, W. (2016). Positive Feelings at School: On the Relationships Between Students' Character Strengths, School-Related Affect, and School Functioning. Journal of Happiness Studies, 17(1), 341-355. https://doi.org/10.1007/s10902-014-9597-1 